\title{
Confirmatory factor analysis sosiomathematics norm among junior high school student
}

\author{
Sri Adi Widodo', Turmudi², Jarnawi Afgani Dahlan ${ }^{3}$, Esti Harini ${ }^{4}$, Fitria Sulistyowati ${ }^{5}$ \\ 1,4,5 Department of Mathematics Education, Universitas Sarjanawiyata Tamansiswa, Indonesia \\ ${ }^{2,3}$ Department of Mathematics Education, Universitas Pendidikan Indonesia, Indonesia
}

\begin{tabular}{l} 
Article Info \\
Article history: \\
Received Dec 13, 2019 \\
Revised Apr 2, 2020 \\
Accepted May 3, 2020 \\
\hline Keywords: \\
Confirmatory factor analysis \\
Experience \\
Explanation of the mathematics \\
Mathematical communication \\
Mathematical differences
\end{tabular}

Article Info

Article history:

Received Dec 13, 2019

Revised Apr 2, 2020

Accepted May 3, 2020

Mathematical differences

\begin{abstract}
The purpose of this study was to confirm the factors that influence the sociomathematics norm. The method used in this research is the ex post facto. The subjects in this study were seventh-grade junior high school students in the city of Yogyakarta, Indonesia (264 students) taken by cluster random sampling. The instrument used was a sociomathematics norm observation sheet consisting of four factors are (1) the experience of mathematics, (2) the explanation of the mathematics, (3) mathematical differences, (4) mathematical communication. Data analysis using structural equation models with the Confirmatory Factors Analysis. The results showed that the modified path analysis obtained goodness of fit mostly in the fit category, so overall the sample covariance matrix is the same as the estimated covariance matrix.
\end{abstract}

This is an open access article under the CC BY-SA license.

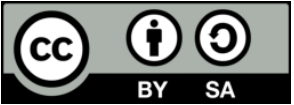

\section{Corresponding Author:}

Sri Adi Widodo,

Department of Mathematics Education,

Universitas Sarjanawiyata Tamansiswa,

Jl. Batikan UH-III/1043 Yogyakarta 55167, Indonesia.

Email: sriadi@ustjogja.ac.id

\section{INTRODUCTION}

Classrooms in schools are a picture of community life on a small scale [1,2]. In social life with a high social sense, a good interaction process must occur between citizens. Things that are not much different occur in the classroom and the school environment. In learning that occurs in the classroom, it is expected that good interaction between students and teachers. If the interaction process is not based on a tolerance between class members, the communication process will not be good. This is because class residents are always suspicious of other citizens. If this is allowed to happen continuously, it can be predicted that students' abilities in social or collaborating in the classroom environment are not optimal. For this reason, social interactions that occur in the classroom environment must be adapted so that class members have good interaction skills [3-5].

Social interactions that occur in mathematics learning are closely related to the negotiation process about procedures for solving problems, especially in learning mathematics [6-8]. The negotiation process that occurs forms a norm or procedure that is often referred to as sociomathematic norms [9-11]. So with sociomathematic norms, social intelligence possessed by each individual can be developed. Sociomatematic norms are closely related to negotiations about what is called problem-solving procedures, about problemsolving procedures such as what is acceptable, about alternative procedures and also about formulating effective procedures [12].

In general, sociomathematics norms are social norms in Mathematics learning [13, 14]. In this regard, Mathematics learning in class will bring up two norms, namely the social norm itself and the norm 
of sociomathematics $[15,16]$. Social norms that arise in learning mathematics are not tied to the topic conveyed by the teacher, but rather emphasize how students submit good opinions and respect the opinions of others. Unlike the norm of sociomathematics, although both are not influenced by the topic of Mathematics presented, but the process of submitting an opinion, respecting opinions, as well as the interactions that are formed must be nuanced mathematically.Sociomatematic norms are norms that regulate social interaction in solving problems related to mathematical problems $[9,17,18]$. Sociomatematic norms are very important to be applied in mathematics learning because with the existence of sociomathematic norms there are rules that must be obeyed by participants in interacting with other students $[19,20]$ so that anyone who wants an opinion can respect others. Besides, it can train students to work with other students.

The experience of mathematics, explanations of mathematics, mathematical differences, and mathematical communication can form sociomathematic norms [9, 17, 18]. Mathematical experience in general that the learning process for students should be doing math, so they need a lot of mathematical experience that children have before entering school $[9,21,22]$. With these experiences, students hope to understand that an affirmation or argumentation must always have a reason [17, 23]. The mathematical explanation is a procedure for solving mathematical problems [24]. With this mathematical explanation, students can communicate every problem-solving process that is presented in the class [18]. Mathematical differences in sociomathematics norms are processes of valuing freedom to explore alternative methods, share their thoughts, and take the risk of examining their misconceptions and errors in reasoning [25]. Mathematical communication of learning mathematics needs to be developed because through mathematical communication students can organize mathematical thinking both verbally and in writing [26]. In addition to mathematical communication, students can provide appropriate responses in response to an argument from a friend who presents a problem-solving procedure [27]. Related to this, the purpose of this study is to confirm Yackel's four aspects, namely experience of mathematics, explanations of mathematics, mathematical differences, and mathematical communication with sociomathematic norms

\section{RESEARCH METHOD}

The method employed in this research is quantitative [28, 29]. The subjects in this study were $7^{\text {th }}$-grade junior high school students in Jogjakarta as many as 264 students taken using cluster random sampling. This study uses Confirmatory Faktor Analysis in data analysis techniques obtained related to the experience of math (P1), explanation of the mathematics (P2), mathematical differences (P3), and mathematical communication (P4). These four aspects are obtained by using the observation sheet of sociomathematics norms. In the aspect of the experience of math, indicators used are (1) how to contribute accordingly and valuable (item number A1 and A2), and (2) how to calculate accurately, efficiently, and elegantly; in the aspect of explanation of the mathematics (item number A3 to A7). In the explanation of the mathematics, the indicator used is how to accept arguments or justifications (item number B8 to B12). In the aspect of mathematical differences, the indicators used are (1) how to calculate mathematical differences (item number C13), and (2) identify, assess similarities, differences between various solutions (item number $\mathrm{C} 14$ to $\mathrm{C} 16$ ); on the mathematical aspects of communication, the indicators used are intellectual autonomy (Item number D17 and D18), how to make sense (item number 19), how to take-asshared underlie communication (Item number D20).

Confirmatory factor analysis involves the specification and estimation of one or more putative models of factor structure, each of which proposes a set of latent variables (factors) to account for covariances among a set of observed variables. LISREL VIII is used to describe alternative models and to test the fit of each hypothesized model against the sample data [30, 31]. Model specification is accomplished by fixing or constraining elements in three matrices that are analogous to the factor pattern matrix, factor correlation matrix, and communalities from common factor analysis. Higher-order factor models require the specification of an additional matrix containing loadings of the first-order factors on the higher-order factors.

In this study, the analysis proceeds in three steps. First, based on logic, theory and previous studies, plausible alternative models of an underlying data structure are proposed. Using several goodness-of-fit indexes, confirmatory factor analysis is used to compare the data-model fit and examine the evidence for a higher-order construct. One model is selected as best representing the underlying factor structure in the sample data. The model used in this study can be shown in Figure 1. Second, confirmatory factor analysis is used to assess the reliability and validity of the factors and items in the selected model. Third, to crossvalidate these results, goodness-of-fit indexes for the plausible alternative models. 


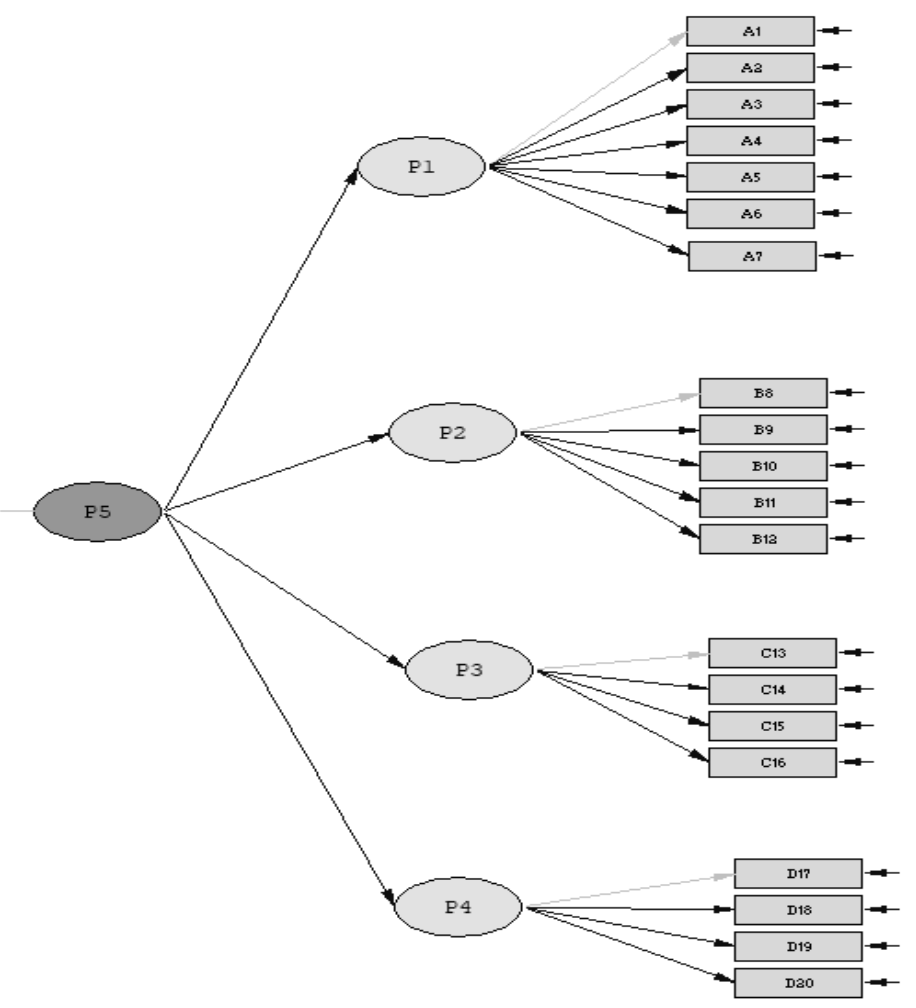

4 first order factor, and 1 second order factor

Figure 1. Model of confirmatory factor analysis sociomathematics norm

\section{RESULTS AND DISCUSSION}

The results of the calculation of the validity and reliability test of the first order Confirmatory Factor Analysis using the Lisrel 8.70 program on each observation item to the aspect of sociomathematic norms are presented in Table 1. In Table 1, testing the validity of the first order Confirmatory Factor Analysis model is obtained that the standardized loading factor index is at least 0.73. An item is considered valid if a standardized loading factor above 0.70 is obtained for educational research [32], the standardized loading factor coefficient between 0.50 to 0.69 is still acceptable [33, 34]. In connection with this opinion and the results of testing the validity can be decided that the loading factor used can be declared valid.

Table 1. Validity and reliability test first order confirmatory factor analysis

\begin{tabular}{|c|c|c|c|c|c|c|c|}
\hline Variable Laten & Manifest Variable & ELF & $\delta$ & Note & $\mathrm{CR}$ & AVE & Decision \\
\hline \multirow{7}{*}{ Experience of math } & $\mathrm{A} 1$ & 0.78 & 0.39 & Valid & \multirow{7}{*}{0.813} & \multirow{7}{*}{0.623} & \multirow{7}{*}{ Reliable } \\
\hline & $\mathrm{A} 2$ & 0.79 & 0.37 & Valid & & & \\
\hline & A3 & 0.81 & 0.35 & Valid & & & \\
\hline & A4 & 0.81 & 0.35 & Valid & & & \\
\hline & A5 & 0.73 & 0.47 & Valid & & & \\
\hline & A6 & 0.82 & 0.33 & Valid & & & \\
\hline & A7 & 0.78 & 0.39 & Valid & & & \\
\hline \multirow{5}{*}{ Explanation of the mathematics } & B8 & 0.73 & 0.47 & Valid & \multirow{5}{*}{0.831} & \multirow{5}{*}{0.583} & \multirow{5}{*}{ Reliable } \\
\hline & B9 & 0.83 & 0.31 & Valid & & & \\
\hline & B10 & 0.73 & 0.47 & Valid & & & \\
\hline & B11 & 0.72 & 0.47 & Valid & & & \\
\hline & B12 & 0.80 & 0.35 & Valid & & & \\
\hline \multirow{4}{*}{ Mathematical differences } & $\mathrm{C} 13$ & 0.79 & 0.38 & Valid & \multirow{4}{*}{0.834} & \multirow{4}{*}{0.646} & \multirow{4}{*}{ Reliable } \\
\hline & $\mathrm{C} 14$ & 0.74 & 0.45 & Valid & & & \\
\hline & $\mathrm{C} 15$ & 0.87 & 0.25 & Valid & & & \\
\hline & $\mathrm{C} 16$ & 0.81 & 0.35 & Valid & & & \\
\hline \multirow{4}{*}{ Mathematical communication } & D17 & 0.74 & 0.45 & Valid & \multirow{4}{*}{0.770} & \multirow{4}{*}{0.582} & \multirow{4}{*}{ Reliable } \\
\hline & D18 & 0.66 & 0.56 & Valid & & & \\
\hline & D19 & 0.84 & 0.29 & Valid & & & \\
\hline & D20 & 0.80 & 0.36 & Valid & & & \\
\hline
\end{tabular}

Int. J. Eval. \& Res. Educ. Vol. 9, No. 2, June 2020: 448 - 455 
In Table 1, it was found that the index construct reliability was 0.813 for mathematical experience, 0.831 for a mathematical explanation, 0.834 for mathematical differences, and 0.770 for mathematical communication. The extracted variant obtained 0.623 for mathematical experience, 0.583 for a mathematical explanation, 0.644 for mathematical differences, and 0.582 for mathematical communication. A factor or aspect tested for reliability has at least a construct reliability index and an extracted variant of 0.50 [35]. In connection with this opinion and the results of the calculation of reliability in the first order, Confirmatory Factor Analysis obtained that all indicators have a Critical Variable more than 0.5 and the average variance extracted more than 0.5. These results indicate that aspects or indicators in the first order Confirmatory Factor Analysis are declared reliable. The results of the calculation of the validity test of the second-order Confirmatory Factor Analysis model using the Lisrel 8.70 program on aspects or indicators of sociomathematics norms are presented in Table 2.

In testing the validity of the second-order Confirmatory Factor Analysis model, an item is considered valid if a standardized loading factor above 0.70 is obtained for educational research [32], and the standardized loading factor coefficient between 0.50 to 0.69 is still acceptable $[33,34]$. The results in Table 2, show that most items already have a standardized loading factor of 0.70 . Based on these results, all indicators or aspects used can be declared valid because it has a standardized loading factor coefficient of more than 0.70 .

In reliability testing, construct reliability is to test the reliability of the construction of an Instrument at least 0.50 , as well as the variant extracted to test the reliability of the construction of an Instrument at least 0.50 [35]. The results of the reliability calculation on the second-order Confirmatory Factor Analysis shown in Table 4 show that all aspects or indicators have a Critical Variable of more than 0.5 and the average variance extracted is more than 0.5 . These results indicate that all loading factors are declared reliable. After knowing the validity and reliability of the loading factor, the next step is to test the matching model or goodness of fit (GOF). The results of the Confirmatory Factor Analysis calculation using Lisrel can be summarized as in Table 3 .

Table 2. Validity and reliability test of the second order confirmatory factor analysis

\begin{tabular}{ccccc}
\hline Variable Laten & Manifest Variable & Estimasi Loading Factor & CR & AVE \\
\hline Experience of math & P1 & 0.97 & & \\
Explanation of the mathematics & P2 & 1.04 & 0.799 & 0.609 \\
Mathematical differences & P3 & 0.92 & \\
Mathematical communication & P4 & 0.98 & & \\
\hline
\end{tabular}

Table 3. Summary goodness of fit

\begin{tabular}{|c|c|c|c|}
\hline GOF Size & Estimation & Criteria & decision \\
\hline Statistik $\chi^{2}$ & $\begin{array}{c}\mathrm{df}=166 \\
\chi 2=876.40\end{array}$ & $\begin{array}{c}0 \leq \chi^{2} \leq 2 d f \\
2 d f<\chi^{2} \leq 3 d f\end{array}$ & Not fit \\
\hline $\mathrm{p}$-value & 0.00 & $\begin{array}{l}0.05 \leq p \leq 1.00 \\
0.01 \leq p<0.05\end{array}$ & Not fit \\
\hline $\mathrm{NCP}$ & 846.13 & must be small & Not fit \\
\hline RMSEA & 0.14 & $\begin{array}{l}R M S E A \leq 0.08 \\
R M S E A=0.05\end{array}$ & Not fit \\
\hline ECVI & $\begin{array}{c}4.18 \\
1100.13\end{array}$ & $\begin{array}{l}\text { Must be less than saturated ECVI }(1.60) \\
\text { Must be less than saturated AIC }(420.00)\end{array}$ & Not fit \\
\hline $\begin{array}{l}\text { Model AIC } \\
\text { Model CAIC }\end{array}$ & $\begin{array}{c}1100.13 \\
17830.96\end{array}$ & $\begin{array}{l}\text { Must be less than saturated AIC (420.00) } \\
\text { Must be less than saturated CAIC (1380.95) }\end{array}$ & $\begin{array}{l}\text { Not fit } \\
\text { Not Fit }\end{array}$ \\
\hline АН & 0.95 & $\begin{array}{c}N F I>0.90 \\
0.80<p \leq 0.90\end{array}$ & Fit \\
\hline TLI or NNFI & $\begin{array}{l}0.95 \\
0.83\end{array}$ & $0.80 \leq T L I<0.90$ & Not fit \\
\hline PNFI & 0.83 & Must a big & Not fit \\
\hline $\mathrm{CFI}$ & 0.96 & $\begin{array}{c}C F I>0.97 \\
0.90<C F I \leq 0.97\end{array}$ & Fit \\
\hline IFI & 0.96 & $\begin{array}{c}I F I>0.97 \\
0.80<I F I \leq 0.97\end{array}$ & Acceptable \\
\hline RFI & 0.94 & $\begin{array}{c}R F I>0.90 \\
0.80<R F I \leq 0.97\end{array}$ & Fit \\
\hline $\mathrm{CN}$ & 64.41 & $\mathrm{CN}>200$ & Not fit \\
\hline SRMR & 0.060 & $\begin{array}{c}S M S R \leq 0.05 \\
0.01<S M S R<0.05\end{array}$ & Not fit \\
\hline GFI & 0.72 & $\begin{array}{c}G F I>0.90 \\
0.80<G F I \leq 0.90\end{array}$ & Not fit \\
\hline AGFI & 0.65 & $\begin{array}{c}A G F I>0.89 \\
0.80<A G F I \leq 0.89\end{array}$ & Not fit \\
\hline PGFI & 0.57 & Approaching to 1 & Not fit \\
\hline
\end{tabular}


Based on the results of the Goodness of Fit calculation summarized in Table 3, it appears that most are in the category of not fit, the Confirmatory Factor Analysis pathway model of sociomathematic norms can be concluded as not fit. This means that overall the sample covariance matrix differs from the estimated covariance matrix, and Confirmatory Factor Analysis pathways sociomathematic norms need to be adjusted.

Modifications are made based on the suggestions in the section The Modification Indices LISREL. The results of the calculation of the complete Second-Order Confirmatory Factor Analysis and The Modification Indices LISREL can be seen in the appendix. For the second-order Confirmatory Factor Analysis model, modifications can be described as shown in Figure 2. The results of the calculation of the validity of the second-order Confirmatory Factor Analysis modification using the Lisrel 8.70 program for each observation item to aspects or indicators of sociomathematic norms are presented in Table 4.

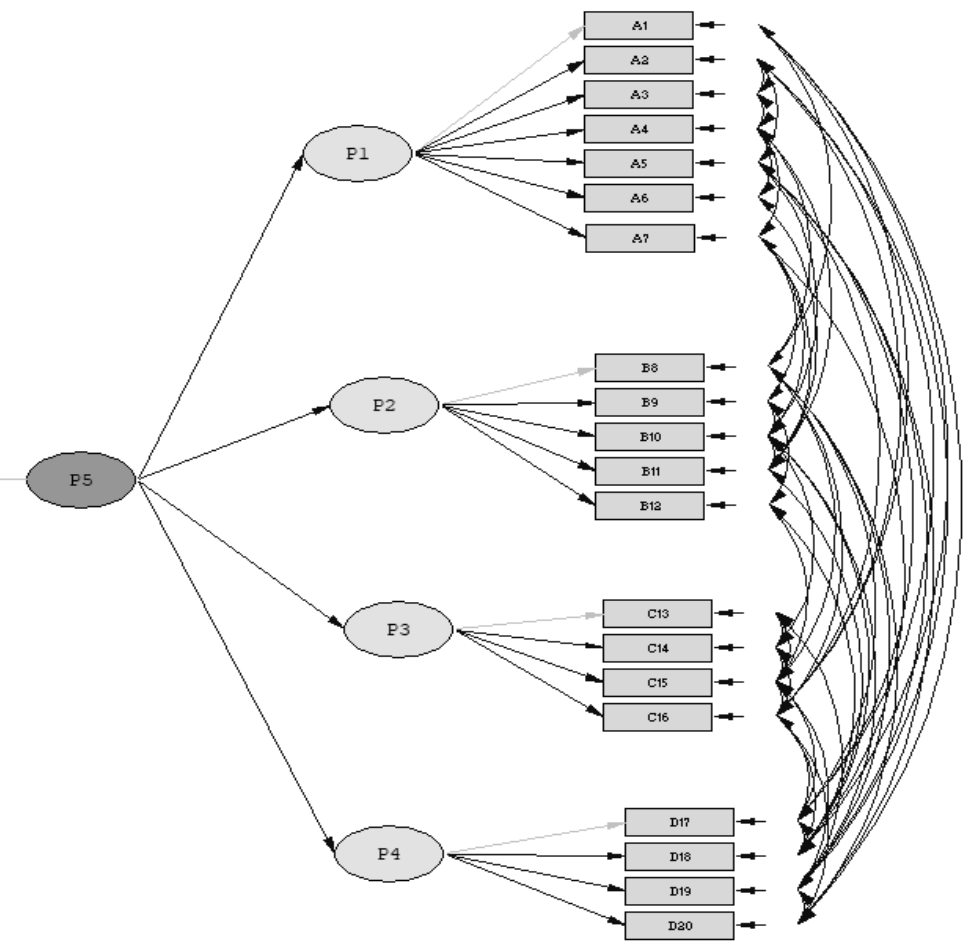

Figure 2. Path of second-order confirmatory factor analysis modification

Table 4 . Validity and reliability test second-order confirmatory factor analysis modification

\begin{tabular}{|c|c|c|c|c|c|c|c|}
\hline Variable Laten & MV & ELF & $\delta$ & Ket & $\mathrm{CR}$ & AVE & Decision \\
\hline \multirow{7}{*}{ Experience of math } & A1 & 0.77 & 0.41 & Valid & \multirow{7}{*}{0.818} & \multirow{7}{*}{0.622} & \multirow{7}{*}{ Reliable } \\
\hline & A2 & 0.79 & 0.37 & Valid & & & \\
\hline & A3 & 0.79 & 0.38 & Valid & & & \\
\hline & A4 & 0.81 & 0.35 & Valid & & & \\
\hline & A5 & 0.75 & 0.40 & Valid & & & \\
\hline & A6 & 0.82 & 0.33 & Valid & & & \\
\hline & A7 & 0.79 & 0.37 & Valid & & & \\
\hline \multirow{5}{*}{ Explanation of the mathematics } & B8 & 0.71 & 0.50 & Valid & \multirow{5}{*}{0.819} & \multirow{5}{*}{0.570} & \multirow{5}{*}{ Reliable } \\
\hline & B9 & 0.82 & 0.32 & Valid & & & \\
\hline & B10 & 0.72 & 0.48 & Valid & & & \\
\hline & B11 & 0.73 & 0.47 & Valid & & & \\
\hline & B12 & 0.79 & 0.37 & Valid & & & \\
\hline \multirow{4}{*}{ Mathematical differences } & $\mathrm{C} 13$ & 0.80 & 0.36 & Valid & \multirow{4}{*}{0.827} & \multirow{4}{*}{0.638} & \multirow{4}{*}{ Reliable } \\
\hline & $\mathrm{C} 14$ & 0.77 & 0.40 & Valid & & & \\
\hline & $\mathrm{C} 15$ & 0.86 & 0.27 & Valid & & & \\
\hline & C16 & 0.76 & 0.43 & Valid & & & \\
\hline \multirow{4}{*}{ Mathematical communication } & D17 & 0.75 & 0.44 & Valid & \multirow{4}{*}{0.771} & \multirow{4}{*}{0.585} & \multirow{4}{*}{ Reliable } \\
\hline & D18 & 0.67 & 0.55 & Valid & & & \\
\hline & D19 & 0.84 & 0.30 & Valid & & & \\
\hline & D20 & 0.79 & 0.37 & Valid & & & \\
\hline
\end{tabular}

Int. J. Eval. \& Res. Educ. Vol. 9, No. 2, June 2020: 448 - 455 
The results of the calculation of the validity test of the first order Confirmatory Factor Analysis model as a result of modification using the Lisrel 8.70 program on aspects or indicators of sociomathematics norms are presented in Table 5. In testing the validity of the modified first-order Confirmatory Factor Analysis model, an item is considered valid if a standardized loading is obtained factors above 0.70 for educational research [32], the standardized loading factor coefficient between 0.50 to 0.69 is still acceptable $[33,34]$. The results in Table 5 show that most items already have a standardized loading factor of 0.70 . Based on these results, all indicators or aspects used can be declared valid because it has a standardized loading factor coefficient of more than 0.70 . In reliability testing, construct reliability is to test the reliability of the construction of an Instrument at least 0.50 , as well as the variant extracted to test the reliability of the construction of an Instrument at least 0.50 [35].

Table 5. Validity and reliability test of first order confirmatory factor analysis modification

\begin{tabular}{ccccc}
\hline Variable laten & Manifest Variable & Estimasi Loading Factor & CR & AVE \\
\hline Experience of math & P1 & 0.99 & & \\
Explanation of the mathematics & P2 & 1.04 & 0.796 & 0.605 \\
Mathematical differences & P3 & 0.94 & & \\
Mathematical communication & P4 & 0.98 & & \\
\hline
\end{tabular}

The results of the reliability calculation on the first order Confirmatory Factor Analysis shown in Table 5 show that all aspects or indicators have a Critical Variable of more than 0.5 and the average variance extracted is more than 0.5. These results indicate that all loading factors are declared reliable. After knowing the validity and reliability of the loading factor, the next step is to test the suitability of the modified model or Goodness of Fit (GOF). The results of the calculation of the Confirmatory Factor Analysis modified using Lisrel can be summarized as in Table 6.

Table 6. Summary goodness of fit modification

\begin{tabular}{|c|c|c|c|}
\hline GOF Value & Estimation & Criteria & Decision \\
\hline Statistik $\chi^{2}$ & $\begin{array}{c}\mathrm{df}=112 \\
\chi 2=200.30\end{array}$ & $\begin{array}{c}0 \leq \chi^{2} \leq 2 d f \\
2 d f<\chi^{2} \leq 3 d f\end{array}$ & Fit \\
\hline p-value & 0.00 & $\begin{array}{l}0.05 \leq p \leq 1.00 \\
0.01 \leq p<0.05\end{array}$ & Not fit \\
\hline $\mathrm{NCP}$ & 72.53 & must be small & Acceptable \\
\hline RMSEA & 0.050 & $\begin{aligned} R M S E A & \leq 0.08 \\
R M S E A & =0.05\end{aligned}$ & Acceptable \\
\hline ECVI & 1.45 & Must be less than saturated ECVI (1.60) & Fit \\
\hline Model AIC & 380.53 & Must be less than saturated AIC (420.00) & Fit \\
\hline Model CAIC & 17830.96 & Must be less than saturated CAIC (1380.95) & Not Fit \\
\hline NFI & 0.99 & $\begin{array}{c}N F I>0.90 \\
0.80<p \leq 0.90\end{array}$ & Fit \\
\hline $\begin{array}{l}\text { TLI or NNFI } \\
\text { PNFI }\end{array}$ & $\begin{array}{l}0.99 \\
0.58\end{array}$ & $\begin{array}{c}0.80 \leq T L I<0.90 \\
\text { Must a big }\end{array}$ & $\begin{array}{l}\text { Not fit } \\
\text { Not fit }\end{array}$ \\
\hline $\mathrm{CFI}$ & 0.99 & $\begin{array}{c}C F I>0.97 \\
0.90<C F I \leq 0.97\end{array}$ & Fit \\
\hline IFI & 0.99 & $\begin{array}{c}I F I>0.97 \\
0.80<I F I \leq 0.97\end{array}$ & Fit \\
\hline RFI & 0.98 & $\begin{array}{c}R F I>0.90 \\
0.80<R F I \leq 0.97\end{array}$ & Fit \\
\hline $\mathrm{CN}$ & 197.60 & $\mathrm{CN}>200$ & Not fit \\
\hline SRMR & 0.029 & $\begin{array}{c}S M S R \leq 0.05 \\
0.01<S M S R<0.05\end{array}$ & Fit \\
\hline GFI & 0.93 & $\begin{array}{c}G F I>0.90 \\
0.80<G F I \leq 0.90\end{array}$ & Fit \\
\hline AGFI & 0.88 & $\begin{array}{c}A G F I>0.89 \\
0.80<A G F I \leq 0.89\end{array}$ & Acceptable \\
\hline PGFI & 0.50 & Approaching to 1 & Not fit \\
\hline
\end{tabular}

Based on the results of the Goodness of Fit calculation summarized in table 4.31, it appears that the number of fits, are acceptable and not fit. A small part is in the category of not fit (6 categories) so that the Second Order Confirmatory Factor Analysis path model can be concluded fit. It means that overall the sample covariance matrix is the same as the estimated covariance matrix.

Based on the results of calculations using the Second Order Confirmatory Factor Analysis, it was found that the construct proposed in this study was appropriate even though the proposed path was not yet fit.

Confirmatory factor analysis sosiomathematics norm among junior high school student (Sri Adi Widodo) 
This It can be seen in the goodness of fit (GOF) from the calculation of the Second Order Confirmatory Factor Analysis before being modified. It can be concluded that the conclusion is not fit as many as 14 criteria out of 18 proposed criteria. The condition of unfit criteria shows more than the fit and acceptance criteria. In connection with these results, the Second Order Confirmatory Factor Analysis pathway needs to be modified in the hope of obtaining a fit or acceptable path structure. The result of the calculation of the Second Order Confirmatory Factor Analysis modification path was obtained, that the conclusion was not fit as many as 6 criteria out of 18 proposed criteria. In connection with these results, the Second Order Confirmatory Factor Analysis modification path is concluded as acceptable.

These results indicate that the four aspects of the experience of mathematics, explanations of mathematics, mathematical differences, and mathematical communication confirm the formation of sociomathematics norms of junior high school students, these results are in line with the opinions of Yackel, et al [9, 17, 18]. To find out most of the supposed indicators of experience of mathematics, explanations of mathematics, mathematical differences, and mathematical communication of sociomathematic norms, can be seen in Table 7. Table 7 shows that the coefficient of the influence of mathematical experience on sociomathematics norms is 0.99 , the coefficient of mathematical explanation of sociomathematics norms is 1.04, Mathematical coefficients on sociomathematics norms are 0.90, Mathematical communication coefficient on sociomathematics norms is 0.90 . Also, it was obtained that the coefficient $\mathrm{T}$ is greater than $\mathrm{Z}=1.96$ so that there is an influence between the two variables [32-34]. In other words, the socio-mathematical norm is confirmed by the four predetermined indicators, are the experience of math, the explanation of the mathematics, mathematical differences, and mathematical communication.

Table 7. Summary of the effects of each indicator on sociomatics norms

\begin{tabular}{ccccc}
\hline Indicator & Coef. variable & $\mathrm{R} 2$ & $\mathrm{~T}$ & $\mathrm{Z}$ \\
\hline Experience of math & 0.99 & 0.98 & 8.01 & 1.96 \\
Explanation of the mathematics & 1.04 & 1.09 & 7.99 & 1.96 \\
Mathematical differences & 0.90 & 0.81 & 7.11 & 1.96 \\
Mathematical communication & 0.98 & 0.95 & 6.93 & 1.96 \\
\hline
\end{tabular}

\section{CONCLUSION}

The four indicators namely the experience of mathematics, the explanation of mathematics, mathematical differences, and mathematical communication confirm the norm of sociomathematics. In connection with these results, it can be suggested that the observation sheet of the experience of math, the explanation of the mathematics, mathematical differences, and mathematical communication can be used to measure the sociomathematics norms among junior high school students.

\section{ACKNOWLEDGMENTS}

The authors would like to thank the LPDP for sponsorship of our publications.

\section{REFERENCES}

[1] N. D. Güven and Y. Dede, "Examining social and sociomathematical norms in different classroom microcultures: Mathematics teacher education perspective," Kuram ve Uygulamada Egit. Bilim., vol. 17, no. 1, pp. 265-292, 2017,

[2] S. A. Widodo, J. A. Dahlan, and Turmudi, "Can sociomathematical norms be developed with learning media?" J. Phys. Conf. Ser., vol. 1315, no. 1, pp. 012005, 2019.

[3] F. W. Tung and Y. S. Deng, "Designing social presence in e-learning environments: Testing the effect of interactivity on children," Interact. Learn. Environ., vol. 14, no. 1, pp. 251-264, 2006.

[4] K. H. Huang and Y. S. Deng, "Social interaction design in cultural context: A case study of a traditional social activity," Int. J. Des., vol. 2, no. 2, pp. 81-96, 2008.

[5] H. K. Hvide and P. Östberg, "Social interaction at work," J. financ. econ., vol. 117, no. 3, pp. 628-652, 2015.

[6] A. M. Partanen and R. Kaasila, "Sociomathematical Norms Negotiated in the Discussions of Two Small Groups Investigating Calculus," Int. J. Sci. Math. Educ., vol. 13, no. 4, pp. 927-946, 2015.

[7] L. M. Lopez and L. Allal, "Sociomathematical Norms And The Regulation of Problem Solving in Classroom Microcultures," Int. J. Educ. Res., vol. 46, no. 5, pp. 252-265, 2007.

[8] E. Yackel and C. Rasmussen, "Beliefs and norms in the mathematics classroom," Beliefs a hidden Var. Math. Educ., vol. 31, pp. 313-330, 2003.

[9] E. Yackel and P. Cobb, "Sociomathematical norms, argumentation, and autonomy in mathematics," J. Res. Math. Educ., vol. 27, no. 4, pp. 458-477, 1996.

[10] M. Muhaimin, Kartono, and B. Astuti, "An analysis of sociomathematical norms of elementary school students through collaborative problem solving learning," J. Prim. Educ., vol. 8, no. 3, pp. 67-74, 2019.

Int. J. Eval. \& Res. Educ. Vol. 9, No. 2, June 2020: 448 - 455 
[11] D. Romano, "Pre-service elementary school teachers' perception of rectangle," Inov. u nastavi, vol. 30, no. 2, pp. 158-171, 2017.

[12] G. J. Roy, J. M. Tobias, F. Safi, and J. K. Dixon, "Sustaining social and sociomathematical norms with prospective elementary teachers in a mathematics content course," Investig. Math. Learn., vol. 7, no. 2, pp. 33-64, 2014.

[13] J. K. Dixon, et al, "Do they really need to raise their hands? Challenging a traditional social norm in a second grade mathematics classroom," Teach. Teach. Educ., vol. 25, no. 8, pp. 1067-1076, 2009.

[14] S. E. Kastberg and R. S. Frye, "Norms and mathematical proficiency," Teach. Child. Mathmatics, vol. 20, no. 1, pp. 28-35, 2013.

[15] S. M. Kang and M. K. Kim, "Sociomathematical norms and the teacher's mathematical belief: A case study from a Korean in-service elementary teacher," Eurasia J. Math. Sci. Technol. Educ., vol. 12, no. 10, 2016.

[16] R. I. I. Putri, M. Dolk, and Zulkardi, "Professional development of PMRI teachers for introducing social norms," J. Math. Educ., vol. 6, no. 1, pp. 11-19, 2015.

[17] P. Cobb, E. Yackel, and T. Wood, Affect and mathematical problem solving, Affect and Mathematical Problem Solving, D. B. McLeod and V. M. Adams, Eds. New York: Springer-Verlag, pp. 117-148, 1989.

[18] E. Yackel, P. Cobb, and T. Wood, "Small-group interactions as a source of learning opportunities in second-grade mathematics," J. Res. Math. Educ., vol. 22, no. 5, pp. 390-408, 1991.

[19] I. Biza, E. Nardi, and G. Joel, "Balancing classroom management with mathematical learning: using practice-based task design in mathematics teacher education," Math. Teach. Educ. Dev., vol. 17, no. 2, pp. 182-198, 2015.

[20] A. Pinto and R. Karsenty, "From course design to presentations of proofs: How mathematics professors attend to student independent proof reading," J. Math. Behav., vol. 49, pp. 129-144, 2018.

[21] W. Scott, P. J. Davis, and R. Hersh, "The mathematical experience," Math. Gaz., vol. 66, no. 435, pp. 73-74, 1982.

[22] I. Masitoh and S. Prabawanto, "Improving understanding of mathematical concepts and mathematical critical thinking ability of grade $\mathrm{v}$ students in primary schools through explorative learning (in Bahasa)," EduHumaniora | J. Pendidik. Dasar Kampus Cibiru, vol. 7, no. 2, pp. 186-197, 2016.

[23] V. Albe, "When scientific knowledge, daily life experience, epistemological and social considerations intersect: Students' argumentation in group discussions on a socio-scientific Issue," Res. Sci. Educ., vol. 38, no. 1, pp, 67-90, 2008

[24] E. A. Forman, D. E. Mccormick, and R. Donato, "Learning what counts as a mathematical explanation," Linguist. Educ., vol. 9, no. 4, pp. 313-339, 1997.

[25] E. Young, "Unpacking mathematical content through problem solving," $\mathrm{PhD}$ Thesis, The University of Oklahoma, 2002. [Online]. Available : https://shareok.org/handle/11244/510

[26] R. Driver, P. Newton, and J. Osborne, "Establishing the norms of scientific argumentation in classrooms," Sci. Educ., vol. 83, no 4, pp. 287-312, 2000.

[27] B. Pedemonte, "How can the relationship between argumentation and proof be analysed?" Educ. Stud. Math., vol. 66, no. 1, pp. 23-44, 2007.

[28] J. W. Creswell, Research Design: Qualitative, Quantitative, and Mixed Methods Approaches Second Edition, 2012.

[29] J. W. Creswell, Educational Research: Planning, Conducting and Evaluating Quantitative and Qualitative Research, London: Pearson, 2012.

[30] K. G. Jöreskog and D. Sörbom, LISREL 8: Structural Equation Modeling with the SIMPLIS Command Language Scientific Software International, 1993.

[31] K. G. Jöreskog and D. Sörbom, "Model search with TETRAD II and LISREL," Sociological Methods \& Research, vol. 19, no. 1, pp. 93-106, 1990.

[32] H. Gatignon, Confirmatory factor analysis, in Statistical Analysis of Management Data, New York: Springer, 2010.

[33] I. Ghozali and Fuad, Structural equation modeling: theory, concepts and applications with the LISREL program, Semarang: Badan Penerbit Universitas Diponegoro, 2014

[34] E. Riadi, SEM statistics: structural equation modeling with LISREL, Yogyakarta: Penerbit Andi, 2018.

[35] J. F. Hair, W. C. Black, B. J. Babin, and R. E. Anderson, Multivariate Data Analysis, New Jersey: Pearson, 2014. 